\title{
ICE-protease inhibitors block murine liver injury and apoptosis caused by CD95 or by TNF- $\alpha$
}

\author{
Gerald Künstle $^{\mathrm{a}}$, Marcel Leist ${ }^{\mathrm{b}}$, Stefan Uhlig ${ }^{\mathrm{a}}$, Laszlo Revesz ${ }^{\mathrm{c}}$, Roland Feifel ${ }^{\mathrm{c}}$, \\ Andrew MacKenzie ${ }^{c}$, Albrecht Wendel ${ }^{\mathrm{a}, *}$ \\ a Department of Biochemical Pharmacology, Faculty of Biology, University of Konstanz, POB 5560 M667, D-78434 Konstanz, Germany \\ ${ }^{\mathrm{b}}$ Department of Molecular Toxicology, Faculty of Biology, University of Konstanz, POB 5560 M667, D-78434 Konstanz, Germany \\ ${ }^{\mathrm{c} S a n d o z}$ Pharma, Preclinical Research, $\mathrm{CH}-4002$ Basel Switzerland
}

\begin{abstract}
The two apoptosis receptors of mammalian cells, i.e. the $55 \mathrm{kDa}$ TNF receptor (TNF-R1) and CD95 (Fas/APO1) are activated independently of each other, however, their signaling involves a variety of ICE-related proteases [1]. We used a cell-permeable inhibitor of ICE-like protease activity to examine in vivo whether post-receptor signaling of TNF and CD95 are fully independent processes. Mice pretreated with the inhibitor, Z-VAD-fluoromethylketone (FMK) were dose-dependently protected from liver injury caused by CD95 activation as determined by plasma alanine aminotransferase and also from hepatocyte apoptosis assessed by DNA fragmentation ( $\mathrm{ID}_{50}=0.1 \mathrm{mg} / \mathrm{kg}$ ). A dose of $10 \mathrm{mg} / \mathrm{kg}$ protected mice also from liver injury induced by TNF- $\alpha$. Similar results were found when apoptosis was initiated via $\mathrm{TNF}-\alpha$ or via CD95 in primary murine hepatocytes $\left(\mathrm{IC}_{50}=1.5 \mathrm{nM}\right)$ or in various human cell lines. In addition to prevention, an arrest of cell death by Z-VAD-FMK was demonstrated in vivo and in vitro after stimulation of apoptosis receptors. These findings show in vitro and in vivo in mammals that CD95 and the TNF- $\alpha$ receptor share a distal proteolytic apoptosis signal.
\end{abstract}

Keywords: CPP32; Interleukin-1 $\beta$ converting enzyme; Fas/APO-1; TNF; ICE-like proteases; Caspases

\section{Introduction}

Physiological cell death, i.e. apoptosis can be activated in mammalian cells by at least two different, well-characterized receptors, CD95 (Fas/APO-1) and TNF-receptor 1 (TNF-R1, CD120a). Uncontrolled activation of apoptosis receptors may not only lead to depletion of cell populations in peripheral blood but also to tissue destruction in organs such as the liver. For instance, CD95 receptor expression in liver excisions from patients with chronic hepatitis $\mathrm{C}$, hepatitis B-related cirrhosis and acute liver failure was signifcantly higher than in normal tissue [2,3]. Also CD95

\footnotetext{
* Corresponding author. Tel.: + 497531 882229; fax: + 497531 883099; e-mail: Albrecht.Wendel@Uni-Konstanz.de
}

was unregulated in inflamed liver tissue [2]. Increased levels of CD95 ligand were found during ongoing liver damage [3] and in liver-infiltrating mononuclear cells obtained from patients with chronic hepatitis C [4]. In livers rejected after allograft transplantation frequent occurrence of apoptotic cells has been observed [5], suggesting that hepatocyte cell death in rejected organs may be a consequence of cytokine receptor-stimulated apoptosis.

The role of TNF in liver pathology has also been studied extensively. Experimentally, injection of this cytokine causes acute liver injury in animals [6,7]. When high amounts of endogenous TNF are released due to the systemic presence of inflammogens, overstimulation of the inflammatory response with injury of the liver occurs in experimental animals. Liver injury caused by 
TNF is known to be potentiated by the indirect transcriptional inhibitor D-galactosamine (GalN) [6]. The enhancement of TNF toxicity by GalN is explained by the findings that TNF- $\alpha$ causes apoptosis in liver under the condition of transcriptional arrest [8], suggesting that apoptotic cell death might represent a key mechanism of cytokine-induced toxicity [9]. Several independent signals seem to control apoptosis in the liver, since it was recently shown in vivo that TNF-R 1 and CD95 initiate hepatocyte apoptosis in mice independently of each other [10].

In various cell types it was found that CD95 and TNF-R1 share a common pathway of signal transduction, i.e. the activation of interleukin- $1 \beta$ converting enzyme (ICE)-like proteases (new nomenclature: caspases) in order to initiate apoptosis [11-13]. The evidence that members of this novel cysteine protease family play an important role in apoptosis includes: (i) ICE-like protease activity is unregulated during mammalian apoptosis [13]; (ii) overexpression of ICE-like proteases results in apoptosis [14-18]; (iii) inhibition of ICE-like proteases prevents apoptosis in an in vitro model system [19,20]; and (iv) in ICE knock-out mice some apoptotic processes are defective [21].

It was further shown that other ICE-like proteases, such as CPP32 (cysteine protease P32) serve as a substrate for ICE. This proteolytic cleavage generates enzymatically active ICE-like proteases from the inactive proenzymes and results in subsequent induction of apoptosis. Such a sequence of events has been shown in the liver [13] and also in other systems [22]. It remains open where the suspected sequence of proteolytic interconversions is terminated and whether such an endpoint needs to be reached in order to execute apoptosis. Therefore we investigated whether a post-receptor signal that is needed for induction of apoptosis can be the same for both receptors.

\section{Experimental}

\subsection{Materials}

Benzyloxycarbonyl-val-ala-asp-(OMe) fluoromethylketone (Z-VAD-FMK) was synthesized by Sandoz (Basel, Switzerland). Recombinant TNF- $\alpha$ was obtained from Dr G.R. Adolf, Bender and Co. (Vienna, Austria), D-galactosamine from Roth Chemicals (Karlsruhe, Germany), the nx123 bp molecular weight marker from Gibco (Eggenstein, Germany), the agonistic anti-murine anti-CD95 monoclonal antibody (antiCD95) from Dianova (Hamburg, Germany), the anti-human anti-CD95 monoclonal antibody $\mathrm{CH} 11$ from Immunotech (Marseille, France), benzylcarbonylasp-2,6-dichlorobenzoyloxymethylketone (Z-D-CBK) from Bachem (Heidelberg, Germany) and Ac-asp-glu- val-asp-aldehyd (Ac-DEVD-CHO) from Neosystem (Strasbourg, France). All reagents not further specified were from Sigma (Deisenhofen, Germany).

\subsection{ICE cleaving activity assay}

Z-val-ala-asp-7-amino-4-methyl coumarin (Z-VAD$A M C)$ was used to assay activity by fluorescence quantitation of free AMC at an excitation wavelength of 365 $\mathrm{nm}$ and emission wavelength of $450 \mathrm{~nm}$. Recombinant huICE $(1 \mu \mathrm{g})$ in $20 \mu 110 \mathrm{mM}$ HEPES, pH $7.5,10 \%$ sucrose, $0.1 \%$ CHAPS was mixed with $10 \mu 1$ of inhibitor and $20 \mu 1$ of substrate in 96-well plates and incubated for $120 \mathrm{~min}$ at $37^{\circ} \mathrm{C}$.

\subsection{Inhibition of $I L-1 \beta$ release from $L P S$-stimulated THP-1 cells}

THP- 1 cells $\left(0.5 \times 10^{6}\right)$ were plated in 24 well culture dishes together with $100 \mathrm{U}$ IFN- $\gamma$ in a total volume of $0.9 \mathrm{ml}$ (RPMI1640 medium containing $2 \mathrm{mM} \mathrm{L-glu-}$ tamine and 5\% heat-inactivated fetal calf serum). Inhibitors were added in $100 \mu 13 \mathrm{~h}$ before addition of 10 $\mu \mathrm{l}$ endotoxin $(500 \mu \mathrm{g} / \mathrm{ml})$. After $40 \mathrm{~h}$, media were centrifuged at $1000 \times \mathrm{g}$ for $10 \mathrm{~min}$. IL- $1 \beta$ was assayed in the supernatant by ELISA (Cayman, France).

\subsection{Murine tissue chamber model}

A sterile teflon tissue chamber was subcutaneously implantated into the dorsal region of isofluran-anaesthetized mice as described [24]. Seven days later mice were treated 'locally' with Z-VAD-FMK. Then mediator production was initiated by adding suspension. Exudates were sampled, $4 \mathrm{~h}$ later, centrifuged for removal of cells and stored at $-20^{\circ} \mathrm{C}$ until further determination of IL-1 $\beta$. A vehicle-treated (positive control) and a dexamethasone-treated (standard reference) group was always included. $\mathrm{ID}_{50}$ values were calculated with a non-linear sigmoidal (four parameter) fitting procedure.

\subsection{In vivo experiments}

Male BALB/c mice (25 g) had free access to food and water for the cell preparations, or were starved overnight for the in vivo experiments; D-GalN (700 $\mathrm{mg} / \mathrm{kg}$ body weight) was injected intraperitoneally (i.p.) in $300 \mu 1$ saline. RmuTNF- $\alpha$ or anti-CD95 were given i.v. in a volume of $300 \mu \mathrm{l}$ saline (containing $0.1 \%$ human serum albumin, (HSA)). Z-VAD-FMK was predissolved in pure dimethylsulfoxide (DMSO), diluted with saline and given in a volume of $300 \mu 1(2 \%$ DMSO, i.v.). Blood samples, liver slices for histological studies and liver tissue for analysis of DNA fragmentation were obtained and prepared as described $[8,10]$. 
Table 1

Protection of various cell types against $\mathrm{TNF} \alpha$ - or anti-CD95-induced cell death by inhibition of ICE-like proteases

\begin{tabular}{|c|c|c|c|c|}
\hline \multirow[t]{2}{*}{ Cell type } & \multirow[t]{2}{*}{ Apoptosis-inducing agent } & \multicolumn{3}{|c|}{ Inhibitor of ICE like protease, $\mathrm{IC}_{50}\left(\mathrm{CI}_{95 \%}\right)(\mu \mathrm{M})$} \\
\hline & & Z-D-CBK & $\mathrm{Ac}-\mathrm{DEVD}-\mathrm{CHO}$ & Z-VAD-FMK \\
\hline Murine hepatocytes & Anti-CD95 & $11(8-14)$ & $36(26-52)$ & $0.0015(0.001-0.002)$ \\
\hline Murine hepatocytes & ActD $(400 \mathrm{ng} / \mathrm{ml})+\operatorname{rmuTNF}-\alpha$ & $21(17-25)$ & $79(60-104)$ & $0.027(0.014-0.054)$ \\
\hline HepG2 & ActD $(1.6 \mu \mathrm{g} / \mathrm{ml})+$ anti-CD 95 & $18(15-21)$ & $41(23-72)$ & $4.8(2.9-7.9)$ \\
\hline HepG2 & ActD $(400 \mathrm{ng} / \mathrm{ml})+\operatorname{rhuTNF}-\alpha$ & $19(17-22)$ & $75(57-98)$ & $5.8(1.9-18)$ \\
\hline Jurkat & Anti-CD95 & $1.4(0.2-1.2)$ & $50(12-200)$ & $1.1(0.4-5.6)$ \\
\hline
\end{tabular}

Cells were preincubated for $30 \mathrm{~min}$ with Z-D-CBK, Ac-DEVD-CHO or Z-VAD-FMK. Then $100 \mathrm{ng} / \mathrm{ml} \mathrm{TNF}-\alpha$ or $200 \mathrm{ng} / \mathrm{ml}$ anti-CD95, respectively, were added together with ActD or CHX as indicated. Viability was determined by measurement of LDH release, MTT-reduction and

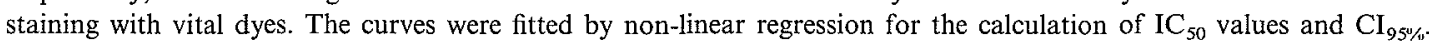

\subsection{Primary murine hepatocyte cultures and cell lines}

Hepatocytes were isolated and cultured as described previously [8]. HepG2 (human hepatoma), HeLa (human cervical carcinoma) and THP1 cells were maintained in RPMI 1640 medium containing 10\% fetal calf serum (FCS) in $75 \mathrm{~cm}^{2}$ flasks. The day before experiments were carried out, HepG2 or HeLa cells were harvested with trypsin/EDTA and plated in $200 \mu 1$ RPMI1640 medium containing 10\% newborn calf serum $(\mathrm{NCS})$ in 24 well plates $\left(1 \times 10^{5}\right.$ cells/well). Before inhibitors and stimuli were added, the medium was exchanged for RPMI1640 medium without serum. TNF- $\alpha$ or anti-CD95 were added 30 min later. Actinomycin D (ActD, $400 \mathrm{ng} / \mathrm{ml}$ for sensitizing murine hepatocytes and HepG2 cells, respectively, towards TNF- $\alpha$; and $1.6 \mu \mathrm{g} / \mathrm{ml}$ for sensitizing HepG2 cells towards anti-CD95) and cycloheximide (CHX, $100 \mu \mathrm{M}$ for sensitizing HeLa cells towards rhuTNF- $\alpha$ ) were added directly after the medium change. Experiments were carried out for $20 \mathrm{~h}$ at $37^{\circ} \mathrm{C}$ in an atmosphere composed of $5 \% \mathrm{CO}_{2} / 40 \% \mathrm{O}_{2} / 55 \% \mathrm{~N}_{2}$.

\subsection{DNA-fragmentation and cytotoxicity}

Lactate dehydrogenase (LDH) [23] was determined in culture supernatants $(S)$, and in the remaining cell monolayer $(C)$ after lysis with $0.1 \%$ Triton $X-100$. The percentage of $\mathrm{LDH}$ release was calculated from the ratio of $S /(S+C)$. Hepatocytolysis in vivo was determined by measuring the plasma activities of alanine aminotransferase (ALT) [23]. DNA fragmentation in hepatocyte cultures or in murine livers was quantitated by measuring cytosolic oligonucleosome-bound DNA using an ELISA-kit (Boehringer, Mannheim, Germany) or analyzed semiquantitatively by electrophoresis on $1.0 \%$ agarose gels as described [8].

\subsection{Statistics}

Data are expressed as means \pm S.D. In vitro experiments were repeated in at least three different cell preparations. Statistical differences were determined by an unpaired $t$-test if applicable or with the unpaired Welch test (in the case of inhomogeneous variances) or by using the Student's-Newman-Keuls test. A $P$ value of less than 0.05 was considered to be significant.

\section{Results}

\subsection{Characterization of Z-VAD-FMK}

Z-VAD-FMK had the following activities in different test systems: (i) in an assay with rhuICE and the fluorogenic substrate $\mathrm{Z}-\mathrm{VAD}$-AMC the $\mathrm{IC}_{50}$ of $\mathrm{Z}$ VAD-FMK for inhibition of ICE was $5.8 \mathrm{nM}(95 \%$ confidence interval $\left(\mathrm{CI}_{95 \%}\right)=3.1-10 \mathrm{nM}$ ); and (ii) the $\mathrm{IC}_{50}$ for inhibition of lipopolysaccharide (LPS)-induced $\mathrm{IL}-1 \beta$ release from THP1 cells was $120 \mathrm{nM}\left(\mathrm{CI}_{95 \%}=\right.$ $30-390 \mathrm{nM}$ ). To confirm these results under in vivo conditions we used an animal tissue chamber model [24] to determine the inhibitory capacity of Z-VAD-FMK on the release of IL-1 $\beta$ after local application into the mouse tissue chamber. The inflammatory response to zymosan administration alone (positive control) resulted in an average release of $2.7 \mathrm{ng} / \mathrm{ml} \mathrm{IL-1} \beta$ into the chamber, compared to amounts below the detection limit, less than $0.1 \mathrm{ng} / \mathrm{ml}$, in control animals challenged only with saline. Z-VAD-FMK inhibited the IL-1 $\beta$ release into the exudate at doses of $1 \mu \mathrm{g}$ or greater. Compared to dexamethasone as a $100 \%$ reference, an $\mathrm{ID}_{50}$ of $2.8 \mu \mathrm{g} /$ chamber was calculated, which corresponds to a dose of about $0.1 \mathrm{mg} / \mathrm{kg}$ body weight in mice. 
We then checked whether Z-VAD-FMK inhibits apoptosis in well-defined cell lines and compared the inhibition to other known inhibitors. Apoptosis in human anti-CD95-sensitive Jurkat cells was inhibited by Z-asp-2,6-dichlorobenzoyloxymethylketone (Z-DCBK), Ac-DEVD-CHO or Z-VAD-FMK as determined by LDH release (Table 1), oligonucleosomal DNA fragmentation and morphological alterations (not shown). Similar observations were made in the TNF- $\alpha$-sensitive human HeLa cell line.

\subsection{Protection of liver cells by Z-VAD-FMK}

Freshly isolated hepatocytes exposed to $200 \mathrm{ng} / \mathrm{ml}$ anti-CD95 undergo apoptotic cell death within $20 \mathrm{~h}$ of incubation as characterized by apoptotic morphology, DNA fragmentation and subsequent LDH release [10]. In this cell system, anti-CD95-induced hepatocyte apoptosis was prevented in a concentration-dependent manner by an inhibitor of ICE-like proteins, i.e. Z-DCBK $\left(\mathrm{IC}_{50}=11 \mu \mathrm{M}\right)$ (Table 1$)$, as well as by an inhibitor of the ICE-like protease CPP32, i.e. AcDEVD-CHO $\left(\mathrm{IC}_{50}=36 \mu \mathrm{M}\right.$; Fig. 1$)$. Compared to these two peptide inhibitors, the ICE inhibitor Z-VADFMK was about three orders of magnitude more potent $\left(\mathrm{IC}_{50}=1.5 \mathrm{nM}\right.$; Fig. 1). In a different set of experiments we examined whether CD95-triggered
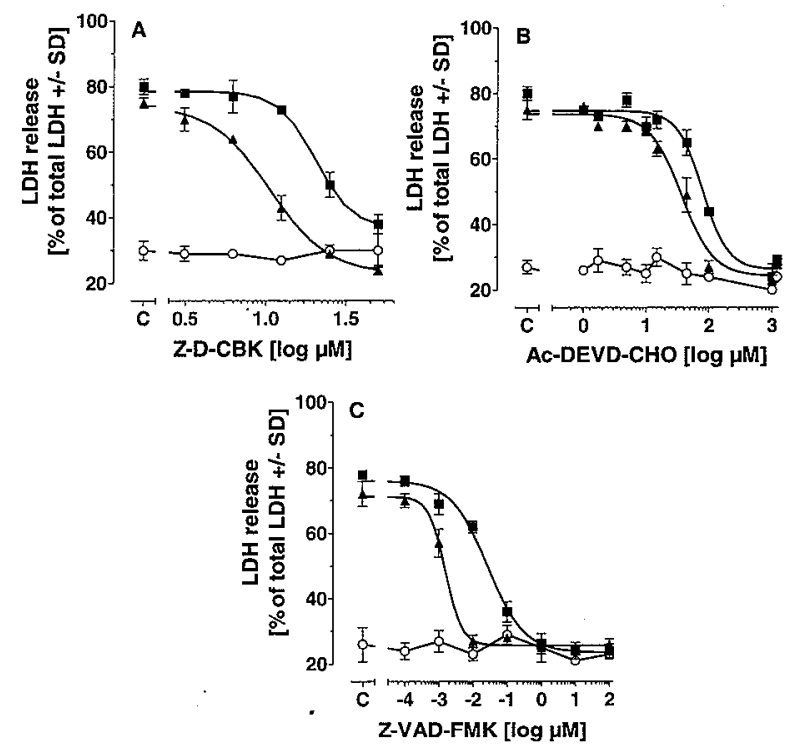

Fig. 1. Protection of primary murine hepatocytes against ActD/ rmuTNF- $\alpha$ or anti-CD95-induced cell death by inhibitors of ICE-like proteases with different potency. Hepatocytes from BALB/c mice were incubated in RPMI1640 medium with various concentrations of inhibitors ((A), Z-D-CBK; (B), Ac-DEVD-CHO; and (C), Z-VADFMK) either alone, together with $400 \mathrm{ng} / \mathrm{ml} \mathrm{ActD}$ and $100 \mathrm{ng} / \mathrm{ml}$ rmuTNF- $\alpha$ or with $200 \mathrm{ng} / \mathrm{ml}$ anti-CD95. After $20 \mathrm{~h}$, LDH-release was determined. C: control (untreated or stimulus alone), $\mathbf{\mathbf { E }}$, ActD/ rmuTNF- $\alpha$, anti-CD95; $O$, inhibitor alone. Data are means of triplicate determinations \pm S.D.
Table 2

Influence of the addition of inhibitors at different timepoints after CD95 receptor stimulation on protection of murine hepatocytes against cell death

\begin{tabular}{lll}
\hline $\begin{array}{l}\text { Timepoint of inhibitor } \\
\text { addition }(\mathrm{h})\end{array}$ & $\begin{array}{l}\text { Final cytotoxicity after } 20 \mathrm{~h} \\
\text { (\% LDH release) }\end{array}$ \\
\cline { 2 - 3 } & $\begin{array}{l}\text { Ac-DEVD-CHO } \\
(400 \mu \mathrm{M})\end{array}$ & $\begin{array}{l}\text { Z-VAD-FMK }(1 \\
\mu \mathrm{M})\end{array}$ \\
\hline 3 & $33 \pm 1.9^{*}$ & $38 \pm 3.1^{*}$ \\
5 & $47 \pm 0.7^{*}$ & $50 \pm 3.7^{*}$ \\
8 & $56 \pm 0.8^{*}$ & $58 \pm 2.3^{*}$ \\
12 & $61 \pm 0.9$ & $66 \pm 2.3$ \\
16 & $67 \pm 2.1$ & $71 \pm 4.1$ \\
Anti-CD95 alone $(t=0)$ & $66 \pm 0.6$ & $68 \pm 3.7$ \\
Control & $24 \pm 3.7$ & $20 \pm 1.5$ \\
\hline
\end{tabular}

Hepatocytes from BALB/c mice were left to adhere to culture plates for $5 \mathrm{~h}$ in $400-\mathrm{hPa}$ oxygen atmosphere. Medium was then substituted by pure RPMI 1640 containing $200 \mathrm{ng} / \mathrm{ml}$ anti-CD 95 . At various timepoints after CD95 receptor stimulation $400 \mu \mathrm{M}$ Ac-DEVD-CHO or $1 \mu \mathrm{M} \mathrm{Z}$-VAD-FMK was added and incubations were continued. After a total incubation time of $20 \mathrm{~h}$, cytotoxicty was determined by measurement of LDH release. Data are means of triplicate determinations \pm S.D.

$* P<0.01$

apoptosis would still be modulated by inhibition of ICE-like proteases after addition of anti-CD95. In fact, significant protection of hepatocytes was observed when Z-VAD-FMK or Ac-DEVD-CHO were added up to $5 \mathrm{~h}$ after anti-CD95 (Table 2). To study TNF- $\alpha$-mediated hepatocyte death, we incubated ActD-sensitized hepatocytes with recombinant murine TNF- $\alpha$ $(\mathrm{rmuTNF}-\alpha)$ in the presence of various inhibitors of ICE-like proteases. The protection afforded by the inhibitors was comparable to the one seen in the CD95 system, i.e. apoptosis was prevented by either inhibition of ICE or inhibition of CPP32 (Table 1). At inhibitor concentrations that completely prevented $\mathrm{LDH}$ release (1 $\mu \mathrm{M}$ Z-VAD-FMK and $400 \mu \mathrm{M}$ Ac-DEVD-CHO) neither oligonucleosomal DNA fragments nor morphological signs of apoptosis were found (not shown). Similar results were observed in the human hepatoma cell line HepG2 exposed to either rhuTNF- $\alpha$ plus 400 $\mathrm{ng} / \mathrm{ml} \mathrm{ActD}$, or to anti-human anti-CD95 plus ActD (Table 1). This indicates that the common inhibition of either apoptosis pathway by Z-VAD-FMK is not limited to the species mouse.

\subsection{Prevention of fulminant liver injury in mice}

Treatment of mice with anti-CD95 induces hepatocyte apoptosis and subsequent liver injury characterized by the release of transaminases and sorbitol dehydrogenase [10]. In this in vivo model, various doses of Z-VAD-FMK were given i.p. $15 \mathrm{~min}$ before intravenous injection of anti-CD95. Liver injury was deter- 
Table 3

Protection of mice by Z-VAD-FMK from liver injury via CD95 or TNF-R1 activation

\begin{tabular}{|c|c|c|c|c|c|c|}
\hline \multirow[t]{2}{*}{ Treatment } & \multirow[t]{2}{*}{ Control } & \multirow[t]{2}{*}{ Solvent control } & \multicolumn{4}{|c|}{ Z-VAD-FMK - $(\mathrm{mg} / \mathrm{kg})$} \\
\hline & & & 0.01 & 0.1 & 1 & 10 \\
\hline Anti-CD95 $5^{\mathrm{a}}$ & $28 \pm 14$ & $8290 \pm 530$ & $8530 \pm 1630$ & $4960 \pm 1210^{*}$ & $140 \pm 43^{* * *}$ & $138 \pm 46^{* * *}$ \\
\hline D-GalN/rmuTNF- $\alpha^{b}$ & $36 \pm 8$ & $4670 \pm 2260$ & $\mathrm{ND}$ & ND & $\mathrm{ND}$ & $184 \pm 102^{* *}$ \\
\hline
\end{tabular}

Animals were injected with $2 \mu \mathrm{g}$ anti-CD95/mouse or saline or a combination of $2 \mu \mathrm{g} \mathrm{TNF}-\alpha / \mathrm{kg}$ body weight (i.v.) and of $700 \mathrm{mg}$ D-galactosamine $/ \mathrm{kg}$ body weight (i.p.). Various doses of Z-VAD-FMK were applicated in a volume of $300 \mu 1$ saline with $2 \%$ dimethylsulfoxide, $15 \mathrm{~min}$ before challenge. Hepatotoxicity was determined after $8 \mathrm{~h}$ by the measurement of plasma ALT (U/l) in blood obtained by cardiac puncture. Data are from one representative experiment and expressed as means +S.E.M. ND, not done.

${ }^{\mathrm{a}} n=3 ;{ }^{\mathrm{b}} n=5$.

$* P<0.05 ; * * P<0.01, * * * P<0.001$ vs. solvent control.

mined $8 \mathrm{~h}$ later by measurement of liver-specific plasma enzyme activities. Hepatocyte cell death was quantified by measurement of hepatic DNA fragmentation in liver homogenates and histological examination of alterations in liver sections. Pretreatment of mice with Z-VAD-FMK conferred dose-dependent protection against CD95-mediated liver injury (Table 3 ). Protection was confirmed by analysis of DNA fragmentation in an agarose gel and by histological examination (not shown). We calculated a value of about $0.1 \mathrm{mg} / \mathrm{kg}$ body weight for half-maximal protection. In an alternative experimental setting, pretreatment by $10 \mathrm{mg}$ Z-VAD-FMK/ $\mathrm{kg}$ body weight protected D-galactosamine (GalN)-sensitized mice from apoptotic liver injury induced by intravenous injection of rmuTNF- $\alpha$ (Table 2). Livers of Z-VAD-FMK-pretreated mice showed no laddering when hepatic DNA was analyzed on agarose gels (not shown).

When Z-VAD-FMK (10 $\mathrm{mg} / \mathrm{kg}$ body weight) was injected $15 \mathrm{~min}$ after the activating anti-CD95 (ALT, injury control: $2440 \pm 1090 \mathrm{U} / \mathrm{l}$ ), we still observed complete protection of the animals from liver injury (ALT: $74 \pm 14 \mathrm{U} / 1$ ) and apoptotic cell death (not shown). This experiment indicates that Z-VAD-FMK is effective even after activation of apoptosis-triggering receptors by their ligands.

\section{Discussion}

CD95 or TNF-R1 represent independent receptor systems of the liver that can induce apoptosis when individually activated by their ligands, i.e. CD95 ligand and $\mathrm{TNF}-\alpha$, respectively [25-27]. In contrast to the selectivity which we observed in vivo on the receptor level [10], our results here demonstrate in vitro and in vivo that the intracellular signaling pathways of both receptors converge to a proteolytic step that can be inhibited by the same compound.

It has been shown previously by a molecular biological approach with $b c l$-2 overexpression, that CD95-mediated murine liver injury can be inhibited by prevention of apoptosis in hepatocytes [28]. These studies prove the principle that interference with the execution step of apoptosis may be a useful therapeutic approach. However, they do not yield defined mechanistic information, since the exact mode of action of $b c l-2$ is still unknown. In our study we demonstrate in vivo that intervention with low-molecular weight inhibitors of defined proteases prevents mammalian tissue apoptosis independent of an effect on the cytokine receptor activated in complex animal models of systemic hyperinflammation. The design of our study did not allow us, at the present state of limited knowledge about the array of ICE-like proteases, to identify the molecular species of the proteolytic activity whose inhibition prevents or arrests apoptosis. Because we cannot exclude that a number of different ICE-like proteases are inhibited by the peptide inhibitors we used, we based our conclusions on the fact that only one of these proteolytic activities is functional in such a distal position that its inhibition is sufficient to block apoptosis. From a practical point of view in medicine, these experiments demonstrate a potential therapeutic principle derived from a known mechanism of action, i.e. inhibition of members of the ICE-like protease family. We believe that a pharmacotherapy based on intervention with the control of apoptosis deserves further consideration, at least because several acute and chronic liver disorders including transplant rejection are known to be associated with overactivation of apoptosis-triggering receptors.

Note added in proof: We wish to acknowledge that similar findings to ours done independently were published after submission of our paper: Rouquet, N, Pagès, J.-C., Molina, T., Briand, P. and Joulin, V. (1996) Curr. Biol. 6, 1192-1195.

\section{Acknowledgements}

This work was supported by the Deutsche Forschungsgemeinschaft (grant We 686/17). 


\section{References}

[1] Glanz, J. (1996) Science 273, 735-737.

[2] Hiramatsu, N., Hayashi, N., Katayama, K., Mochizuki, K., Kawanishi, Y., Kasahara, A., Fusamoto, H. and Kamada, T. (1994) Hepatology 19, 1354-1359.

[3] Galle, P.R., Hofmann, W.J., Walczak, H., Schaller, H., Otto, G., Stremmel, W., Krammer, P.H. and Runkel, L. (1995) J. Exp. Med. 182, 1223-1230.

[4] Mita, E., Hayashi, N., lio, S., Takehara, T., Hilioka, T., Kasahara, A., Fusamoto, H. and Kamada, T. (1994) Biochem. Biophys. Res. Commun. 204, 468-474.

[5] Krams, S.M., Egawa, H., Quinn, M.B., Villanueva, J.C., GarciaKennedy, R. and Martinez, O.M. (1995) Transplantation 59, $621-625$.

[6] Lehmann, V., Freudenberg, M.A. and Galanos, C. (1987) J. Exp. Med. 165, 657-663.

[7] Tiegs, G., Wolter, M. and Wendel, A. (1989) Biochem. Pharmacol. 38, 627-630.

[8] Leist, M., Gantner, F., Bohlinger, I., Germann, P.G., Tiegs, G. and Wendel, A. (1994) J. Immunol. 153, 1778-1787.

[9] Leist, M., Gantner, F., Bohlinger, I., Tiegs, G., Germann, P.G. and Wendel, A. (1995) Am. J. Pathol. 146, 1220-1234.

[10] Leist, M., Gantner, F., Künstle, G., Bohlinger, I., Tiegs, G., Bluethmann, H. and Wendel, A. (1996) Mol. Med. 2, 109-124.

[11] Los, M., van de Craen, M., Penning, L.C., Schenk, H., Westendorp, M., Baeuerle, P.A., Dröge, W., Krammer, P.H., Flers, W. and Schulze-Osthoff, K. (1995) Nature 375, 81-83.

[12] Tewari, M. and Dixit, V.M. (1995) J. Biol. Chem. 270, 32553260.

[13] Enari, M., Talanian, R.V., Wong, W.W. and Nagata, S. (1996) Nature 380, 723-726.

[14] Yuan, J., Shaham, S., Ledoux, S., Ellis, H.M. and Horvitz, R.R. (1993) Cell 75, 641-652.
[15] Miura, M., Hong, Z., Rotello, R., Hartwieg, E.A. and Yuan, J. (1993) Cell 75, 653-660.

[16] Kumar, S., Kinoshita, M., Noda, M., Copeland, N.G. and Jenkins, N.A. (1994) Genes Dev 8, 1613-1626.

[17] Kamens, J., Paskind, M., Hugunin, M., Talanian, R.V., Allen, H., Banach, D., Bump, N., Hackett, M., Johnston, C.G., Li, P., Mankovich, J.A., Terranova, M. and Ghayur, T. (1995) J. Biol. Chem. 270, 15 250-15256.

[18] Wang, L., Miura, M., Bergeron, L., Zhu, H., and Yuan, J. (1994) Cell 78, 739-750.

[19] Nicholson, D.W., Ali, A., Thomberry, N.A., Vaillancour, J.P., Ding, C.K., Gallant, M., Gareau, Y., Griffin, P.R., Labelle, M., Lazebnik, Y.A., Munday, N.A., Raju, S.M., Samulson, M.E., Yamin, T.-T., Yu, V.L. and Miller, D.K. (1995) Nature 376, $37-81$.

[20] Lazebnik, Y.A., Kaufmann, S.R., Desnoyers, S., Poirier, G.G. and Earnshaw, W.C. (1994) Nature 371, 346-347.

[21] Kuida, K., Lippke, J.A., Ku, G., Harding, M.W., Livingston, D.J., Su, M.S.-S. and Flavell, R.A. (1995) Science 267, $2000-$ 2003.

[22] Greidlinger, E.L., Miller, D.K., Yamin, T.-T., Casciola-Rosen, L. and Rosen, A. (1996) FEBS Lett. 390, 299-303.

[23] Bergmeyer, H.U. (1984). Methods of Enzymatic Analysis, 3rd edn., Vol. 82. Verlag Chemie, Weinheim.

[24] Dawson, J., Rordorf-Adam, C., Geiger, T., Towbin, H., Kunz, S., Nguyen, H., Zingel, O., Chaplin, D. and Vosbeck, K. (1993) Agents Actions 38, 247-254.

[25] Wong, H.W. and Goeddel, D.V. (1994) J. Immunol. 152, 1751 1755 .

[26] Grell, M., Krammer, P.H. and Scheurich, P. (1994) Eur. J. Immunol. 24, 2563-2566.

[27] Schulze-Osthoff, K., Krammer, P.H. and Dröge, W. (1994) EMBO J. 13, 4587-4596.

[28] Lacronique, V., Mignon, A., Fabre, M., Viollet, B., Rouquet, N., Molina, T., Porteu, A., Henrion, A., Bouscary, D., Varlet, P., Joulin, V. and Kahn, A. (1996) Nature Med 2, 80-86. 